\title{
Patent Citations and Financial Analysts' Long-Term Growth Forecasts
}

\author{
Jincheol Bae ${ }^{1}$, Wonchang Hur ${ }^{1, *}$, Jaehong Lee ${ }^{2}$ and Jaimin Goh ${ }^{1}$ \\ 1 College of Business Administration, Inha University, Incheon 22212, Korea \\ 2 College of Business Administration, Sangmyung University, Seoul 03016, Korea \\ * Correspondence: wchur@inha.ac.kr; Tel.: +82-32-860-7733
}

Academic Editor: Marc A. Rosen

Received: 9 January 2017; Accepted: 14 May 2017; Published: 19 May 2017

\begin{abstract}
This paper examines the influence of patent citations, a proxy for the quality of firms' innovation outputs, on financial analysts' long-term growth forecasts for firms. We find that financial analysts are more likely to issue long-term forecasts for firms with higher patent citations. In addition, we find that financial analysts' long-term forecasts are more positive for firms with high patent citations. These results imply that patent citations increase financial analysts' coverage, and result in more positive forecasts for firms with impactful patents. Considering that financial analysts play important roles in allocating financial resources in capital markets, our findings suggest that patents are valuable assets for firms in securing capital from capital markets, and are thus essential for the sustainable growth of firms.
\end{abstract}

Keywords: financial analysts; long-term growth forecasts; patent citations; capital markets

\section{Introduction}

In this study, we investigate whether patent citation information affects the decision-making process of financial analysts in making long-term growth forecasts. As patent citations play an essential role in innovation and sustainable growth, analysts' positive assessment on this information will financially aid patent-rich firms. Despite the prominent link between patents and corporate profitability, analyses on analysts' long-term forecasts on the valuation of a firm are limited. Hence, this paper examines this missing link between patent citations and analysts' long-term growth forecasts.

Globalization, technological development, and the transition towards a knowledge economy all increase the importance of technological innovation in estimating firm value in addition to financial information [1]. The existing literature reports that new knowledge, technology, and innovation can be measured directly through products, and indirectly through the contribution of relevant indicators [2]. One vital component of these indicators is patent citation information. Since patents with strong potential future impacts are more likely to be cited than less important ones, prior studies report that patent citations are good proxies for firm innovativeness [3-6], and are associated with positive future firm performance $[7,8]$. Thus, the number of patent citations is, in general, considered a reliable indicator for technological leadership and sustainable future performance.

Financial analysts are important intermediaries who produce and disseminate information about firms' short- and long-term performance in response to firm-specific information, disclosures from competitors or related firms, and stock price movement $[9,10]$. Prior studies have concentrated on the informational role of short-term earnings forecasts [9] and stock recommendations [11,12], but have largely neglected the importance of long-term growth forecasts. However, long-term forecast information is sometimes more important than short-term forecast information. For example, Brown et al. [13] found that five-year forecast errors are more closely related to abnormal stock returns than one-year forecast errors. In addition, Bandyopadhyay et al. [14] found that analysts' long-term 
earnings forecasts account for approximately $60 \%$ of the variation in forecasted price. Bradshaw [15] also showed that analysts' projections of long-term earnings growth can better explain analysts' stock recommendations than valuation models. Overall, expectations about a firm's long-term growth play an important role in determining firm value.

This paper investigates the effects of patent citations on analysts' long-term growth forecasts. Extant literature highlights the increasing importance of intellectual capital information in assessing firm value [16,17]. Therefore, investors rely on patent information to predict firms' future cash flows and value creation potential, as well as to assess sustainable growth opportunities [17,18]. Analysts' allocations of effort across firms depend on their expectations of each firm's future performance [19]. Therefore, we predict that analysts collect and publish more information for firms with more patent citations, thereby promoting firms with healthier financial prospects. Since it usually takes considerable time to realize economic outcomes from patents, we expect that the number of patent citations is associated with long-term growth forecasts by analysts.

This study contributes to our understanding of the quality of patents and their impact on future earnings. Recent research focuses on the role of non-financial information in assessing firm value [1], including patent data, which represents a timely measure of innovation, particularly in the context of a rapidly changing technological landscape. This is an important tool for assessing economic performance through R \& D activities in such an environment. In other words, patents are linked to long-term and sustainable profits, since they represent innovation and realistic outcomes from research across different fields, countries, and periods of time $[3,20]$. We find evidence that the link between patent citations and future performance affects analysts' use of patent information in forecasting long-term earnings.

Our research is also related to literature analyzing analysts' long-term growth forecasts. Prior studies found that long-term growth forecasts are an important information source for stock valuation, cost of equity capital, and investment decision-making [15,21]. Despite the importance of long-term growth forecasts in the accounting and finance literature, there is limited evidence concerning whether long-term growth forecasts convey information promoting precise stock valuation and efficient resource allocation in capital markets. Considering time, effort, and resource constraints, it is costlier for analysts who forecast long-term performance compared with analysts who do not. Thus, long-term forecasts show analysts' ability to generate value-relevant long-term oriented information regarding firms' prospects [22]. We demonstrate the value added by analysts who make efforts to issue long-term growth forecasts for firms with greater patent citations.

The rest of this paper is organized as follows: The next section reviews prior literature and develops our hypotheses. Section 3 describes the sample construction and research design. Section 4 presents empirical results. The final section concludes this study.

\section{Background and Hypotheses}

\subsection{Patent Citation and Coprporate Sustainable Growth}

Knowledge asset (Intangible assets, knowledge assets, and intellectual property (capital) are interchangeable terms. Each term refers to a claim to future benefits that does not have a physical or financial embodiment such as a stock or a bond [23].) has become a preeminent economic resource, and is replacing financial and physical capital as the most important resource for sustainable corporate growth [24,25]. In particular, knowledge stock acquired by technological innovation generates profits by introducing new products, creating new markets, and improving productivity of manufacturing processes [26]. Patent stocks are one of the most important knowledge stocks related to technological innovations. Patent holders are given the right to exclude others from making, using, offering for sale, or selling an invention. These patent rights encourage firms to invest time and effort into developing innovative technologies by protecting the firms' exclusive rights to use patents. Lieberman and Montgomery [27] report patents as an effective tool by which a firm creates technological leadership, and provides a first-mover advantage. 
Generally, patent stocks are measured by the number of patents (patent counts) and the number of citations that patents receive (patent citations). Both measures may reveal two different features of the research and development (R \& D) cycle, with patent counts showing the size of research inputs, and patent citation counts indicating the quality or impact of the research outputs. According to the literature, the distribution of the value of patents is severely skewed because the value of individual patents varies extensively [28]. More significant patents are likely to be cited more frequently, while less important patents are expected to obtain fewer citations. Therefore, simple patent counts are not a good proxy for $\mathrm{R} \& \mathrm{D}$ outcomes. Instead, patent citations may be a better indicator of a firm's innovation capability and sustainability, since it is reflected in its social value $[3,28,29]$. This was also indicated by findings that patent counts correlate with expert opinions on the technological strength of a firm, budgets, and publication of scientific research outcomes, but not with financial performance. Meanwhile, patent citations relate with financial performance, but not with budget, expert opinions, or publication [30].

A large number of citations for a patent indicate that the cited patent has the potential for realizing technologically successful innovations over time. In line with this, prior studies have reported a significant positive association between patent citations, Tobin's $Q$, and future earnings $[7,8,28,31]$. A large number of citations by other firms suggests corporate sustainable growth opportunities in the field, as well as the ability of an innovation to overcome uncertainty regarding economic outcomes. It can also help patent-intensive firms maintain their monopoly, particularly for pioneering firms [32]. For this reason, many researchers concerning innovation have used the number of patent citations as an indicator of the innovative capability of firms that leads to sustainable corporate growth.

Significantly, patent citation information can be informative to market participants in several ways. Firstly, if investors can predict the potential impacts of patent rights, patent information may imply enhanced future productivity and reduced manufacturing costs, resulting in sustainable corporate growth. Next, investors can utilize patent information to estimate potential royalty income from patent licensing. According to Gu and Lev [33], regressions of stock returns on royalty income indicate that the multiple assigned by investors to royalty income is approximately three times larger than the earnings multiple, apparently indicating the higher significance of royalty income. In this way, the information conveyed to investors regarding royalty income from patent licensing is highly relevant for future growth opportunities. Finally, Cohen et al. [34] found that historical information on R \& D success is informative in predicting potential future success of $R \& D$ outcomes. Specifically, they reported that stock returns of firms with higher ratios of $\mathrm{R} \& \mathrm{D}$ expense to sales in the past achieved better performance in the future, than firms with lower ratios.

Despite the evident valuation relevance of patent information, a substantial number of companies engaged in patent licensing choose not to report this information to capital markets [33,35]. This lack of information may be the reason why Cohen et al. [34] reported that the market does not incorporate implications of patent citations for future earnings. Since there are inherent difficulties in estimating the intrinsic value of a patent, the GAAP (Generally Accepted Accounting Principles) suggests that firms expense the related costs of internal R \& D activities as incurred. Therefore, financial statements include information on the input of $\mathrm{R} \& \mathrm{D}$ activities in the form of $\mathrm{R} \& \mathrm{D}$ expenses, and lack information on the value of patents. In addition, current accounting standards have no requirement for firms to disclose the estimated value of knowledge capital, and there are no active and transparent markets for knowledge assets [36]. In this situation, sophisticated market participants such as financial analysts can compensate for this lack of information on the value of patent citations [37].

\subsection{Long-Term Growth Forecasts of Financial Analysts and Corporate Sustainable Growth}

Financial analysts add value to capital markets by disseminating information on firms [38]. They reduce information asymmetry between firms and investors, increasing the efficient allocation of capital market resources [39,40]. Analyst reports often include long-term growth forecasts, as well as short-term growth forecasts, for firms they evaluate. Since analysts do not have to provide long-term growth forecasts, only analysts who have confidence in corporate growth opportunities 
collect long-term firm-specific information. In other words, analysts who are more aware of sustainable corporate growth are likely to issue long-term growth forecasts.

Long-term growth forecasts by financial analysts have received growing attention recently in both academic and practical fields. Long-term growth forecasts are essential because of their influence on valuation estimates [41]. Prior literature reports that investors generally count on analysts' forecasts of long-term growth, because analysts are assumed to have information and timing advantages over model-based forecasts [41-43]. Specifically, the Gordon's growth model [44] documents that a price-to-dividend ratio of 30 means that a $1 \%$ increase in long-term dividend growth results in a $30 \%$ stock return. Hence, even small errors in long-term earnings forecasts that measure the basis of dividend growth can lead to significantly incorrect valuations. In a similar vein, Jung et al. [22] reported the relevance of analysts' long-term forecasts on stock prices, and Copeland et al. [45] showed that revisions in long-term analyst forecasts represent a more significant impact on stock prices than revisions in short-term analyst forecasts. In summary, long-term analyst forecasts are an important collection of expectations regarding corporate long-term earnings growth.

DeFond and Hung [46] reported that financial analysts react to market-based incentives to provide investors with value-relevant information. In particular, they find that analysts tend to forecast cash flows for firms whose accounting, operating, and financing characteristics suggest that cash flows are useful in interpreting earnings and assessing firm value. Moreover, among outside investors, institutional investors tend to serve as important intermediaries of analysts' reputations [47]. Since institutional investors tend to be sophisticated users of analysts' reports, analysts are more likely to supply detailed information for their decision-making. Therefore, analysts are more inclined to provide detailed research reports, including corporate long-term prospects, when they recognize long-term prospects are important for the valuation of their stocks.

Recent research suggests that the issuance of long-term growth forecasts signals analysts' ability to generate value-relevant information concerning firms' long-term prospects [22]. In addition, the evidence that long-term growth forecasts issued by Value Line analysts are more accurate than several other metrics computed by Rozeff [48]. Further, the fact that not all financial analysts provide long-term growth forecasts support the required costs involved in creating and reporting long-term growth forecasts. As a result, analysts' reports accompanied by long-term growth forecasts show a stronger market reaction than ones accompanied by only short-term growth forecasts. For example, La Porta [49] found that investment strategies based on long-term growth forecasts can expect higher returns, consistent with those of value stock. Furthermore, Dechow and Sloan [50] also show that stock prices naively reflect analysts' long-term forecasts, rather than extrapolation from past performance. In summary, prior studies suggest that the publication of long-term growth forecasts plays a key role in firm valuation and the credibility of analysts' reports.

Overall, financial analysts add value to investors by transforming public and private information into earnings forecasts which are useful for investment decisions [51,52]. Compared to investors' ability to assess corporate growth, investors have difficulties in interpreting the value and earnings effects of growth information, such as patents [53]. This lack of investors' knowledge regarding the valuation impact of patents increases the value of analysts applying this information to assess firm value and corporate sustainable growth. Given that analysts are not required to issue long-term growth forecasts, the issuance of long-term growth forecasts for firms with patent citations would compensate for this lack of information, potentially increasing financial support through equity markets by facilitating the enhanced valuation of patent-intensive firms.

\subsection{Hypothesis Development}

Recent studies have investigated the value-relevance of technical innovations such as patents, motivated by the increasing importance of these indicators and their contribution to sustainable growth [23,54-56]. Specifically, technical innovations create continuous economic profits by producing new products, forming new markets, and increasing productivity of manufacturing processes. To boost 
sustainable growth, companies should be financially supported in order to reinvest in innovative technology and create knowledge spillover effects.

Previous literature reports that the extent to which a patent is referenced by later patents indicates the economic value and technological significance of the patents. For instance, Trajtenberg [3] showed that the intensity of citation is positively associated with the social value. Similarly, Lanjouw and Schankerman [57] suggested that litigated patents are cited more frequently than their non-litigated counterparts, consistent with an association between citation intensity and economic value. These results suggest that patent citation is a significant indicator of an innovator for successful products, a firm's innovation capabilities, and corporate sustainable growth.

However, patent citation is not denoted in monetary units, making it difficult to explain the effect of patent citation on future profitability. The highly technical features of patent information also hinder a clear interpretation of the implications of patent citation impact for sustainable growth. These inherent difficulties, and the related costs of processing patent citation information into valuation, may hamper investors' processing of patent citation information into the stock valuation. This lack of investors' knowledge concerning the patent stock valuation evokes the incentives for financial analysts to issue growth forecasts that incorporate the impact of patent citations on corporate sustainable growth. These forecasting activities will activate markets for technical innovation, which are increasingly important for the dispersion of knowledge, by providing sustainable financial benefits.

In line with this, we examine whether there is a relationship between patent citations and analysts' issuance of long-term growth forecasts in the context of sustainable corporate growth. Considering the importance of patent information in sustainable corporate growth, we expect a greater number of patent citations to be positively associated with the frequency of long-term growth forecasts. Since analysts tend to increase research regarding high-performing firms, which generally generates more commission revenues for their brokerages (e.g., trading commissions or potential benefits from future investment banking businesses), analysts provide long-term growth forecasts for firms whose long-term prospects are especially important for the valuation of their stocks [19]. Therefore, the first hypothesis is as follows:

Hypothesis 1. The number of patent citations is associated with the likelihood of long-term forecasts by financial analysts.

Our second hypothesis relates to how patent information affects signed forecast errors. Given that the number of patent citations is positively associated with long-term firm performance, we expect analysts who recognize this relationship to issue more optimistic earnings forecasts, compared with those who do not. Furthermore, long-term forecasts have a longer horizon signal [58]. If analysts expect that patent-rich firms will outperform competitors over the long term, they will issue more favorable long-term forecasts. This argument leads to the second hypothesis:

Hypothesis 2. The number of patent citations is associated with favorable long-term forecasts by financial analysts.

\section{Research Design and Sample Description}

\subsection{Sample Selection}

Sample firms used in this study were obtained from the comprehensive patent database compiled by the National Bureau of Economics Research (NBER). This database covers all utility patents granted by the U.S. Patent and Trademark Office, and includes information on references to prior relevant inventions made by patent owners in patent applications. Table 1 reports the distribution of the 74,052 firm-year observations across industries. A total of 27 two-digit SIC industries are included in our sample: (1) in using two-digit SIC industries, we divide our sample into 10 industries according to the classification by the U.S. Department of Labor (https:/ / www.osha.gov/pls/imis/sic_manual.html). 
(2) We excluded financial institutions and government-owned enterprises. (3) Since there is a high number of companies included in the manufacturing industry, manufacturing has been divided into 20 sub-categories.

Table 1. The Distribution of Sample by Industry.

\begin{tabular}{|c|c|c|c|}
\hline Industry & $\mathbf{N}^{1}$ & Mean of Patent ${ }^{2}$ & Mean of Cite ${ }^{3}$ \\
\hline Agriculture, Forestry, and Fishing & 258 & 158 & 1165 \\
\hline Mining & 1950 & 107 & 872 \\
\hline Construction & 402 & 40 & 226 \\
\hline Food and Kindred Products & 1692 & 62 & 405 \\
\hline Tobacco Products & 107 & 137 & 729 \\
\hline Textile Mill Products & 649 & 27 & 144 \\
\hline Apparel and Other Finished Products Made From Fabrics and Similar Materials & 653 & 12 & 57 \\
\hline Lumber and Wood Products, Except Furniture & 428 & 34 & 251 \\
\hline Furniture and Fixtures & 682 & 56 & 521 \\
\hline Paper and Allied Products & 1200 & 227 & 2507 \\
\hline Printing, Publishing, and Allied Industries & 774 & 16 & 154 \\
\hline Chemicals and Allied Products & 9969 & 272 & 1927 \\
\hline Petroleum Refining and Related Industries & 789 & 600 & 3456 \\
\hline Rubber and Miscellaneous Plastics Products & 1,380 & 68 & 376 \\
\hline Leather and Leather Products & 220 & 13 & 106 \\
\hline Stone, Clay, Glass, and Concrete Products & 636 & 134 & 748 \\
\hline Primary Metal Industries & 1462 & 76 & 360 \\
\hline Fabricated Metal Products, Except Machinery and Transportation Equipment & 1792 & 46 & 276 \\
\hline Industrial and Commercial Machinery and Computer Equipment & 8017 & 274 & 2697 \\
\hline Electronic and Other Electrical Equipment and Components & 9616 & 317 & 3319 \\
\hline Transportation Equipment & 2444 & 490 & 3,514 \\
\hline Measuring, Analyzing, and Controlling Instruments & 8625 & 145 & 1334 \\
\hline Miscellaneous Manufacturing Industries & 1117 & 35 & 303 \\
\hline Transportation, Communications, Electric, Gas, and Sanitary Services & 4316 & 77 & 871 \\
\hline Wholesale Trade & 1586 & 50 & 291 \\
\hline Retail Trade & 1446 & 7 & 86 \\
\hline Finance, Insurance, and Real Estate & 2283 & 29 & 299 \\
\hline Services & 9559 & 160 & 2045 \\
\hline Total & 74,052 & 190 & 1743 \\
\hline
\end{tabular}

${ }^{1} \mathrm{~N}$ is the number of firm-year observations in each industry. ${ }^{2}$ Mean of Patent is the average number of patents per observation in each industry. ${ }^{3}$ Mean of Cite is the average number of patent citations per observation in each industry.

We obtained data concerning analysts' long-term growth forecasts from the IBES (Institutional Brokers Estimate System) database, and financial variables from Compustat. By combining patent data, analysts' long-term growth forecasts, and financial variables, we then acquired analyst-firm-year observations. This data included only U.S. firms with accounts closing in December. Again, we deleted observations from financial industry firms, firms with unclassified industry codes, firms without relevant financial data for this study, and firms without at least one analyst forecast covering the current and next years.

A total of 79,302 analyst-firm-year level observations that met the aforementioned criteria were identified between 1 January 1987 and 31 December 2006. Furthermore, the top and bottom 1\% of independent and dependent variables were winsorized.

\subsection{Test of Patent Citations on the Frequency of Long-Term Growth Forecasts by Analysts}

Our first hypothesis predicts that the number of patent citations is positively related to the long-term forecasts of firms. To test this hypothesis, we estimate using the following Equation (1):

$$
\begin{gathered}
L O N G_{t}=\alpha_{0}+\beta_{1} \text { CITE }_{t}+\beta_{2} \text { PATENT }_{t}+\beta_{3} \text { SIZE }_{t}+\beta_{4} L E V_{t} \\
+\beta_{5} R O A_{t}+\beta_{6} \text { FIN }_{t}+\beta_{7} C O M P_{t}+\sum I N D+\sum Y R+\varepsilon_{t}
\end{gathered}
$$

where,

$L O N G_{t}=$ Indicator variable set to 1 if financial analyst $\mathrm{j}$ issues a long-term (one-year ahead) growth forecast for firm $i$ during year $t$, and 0 otherwise; 
CITE $_{t}=$ Natural logarithm of the total number of citations that a firm's patent stock received thus far (year $t$ ) from other firms' patents;

PATENT $_{t}=$ Natural logarithm of patent counts in year $t$, the accumulative number of patents granted in year $t$;

$S I Z E_{t}=$ Natural logarithm of total assets;

$L E V_{t}=$ Total liabilities/total assets;

$R O A_{t}=$ Net income $/$ total assets;

$F I N_{t}=($ Debt financing + equity financing $) /$ total assets;

$C O M P_{t}=$ Number of firms which analysts announce forecasts during year $\mathrm{t}$.

Consistent with prior studies, the long-term forecast, $L O N G$, is defined as an indicator variable that equals one if the observation is associated with long-term earnings growth forecasts as reported in IBES, and zero otherwise. CITE indicates the number of new patent citations in the current year. CITE is measured using the natural logarithm of the total number of citations that a firm's patent stock has received thus far (year $t$ ) from other firms' patents. Based on hypothesis 1 , we predict that $\beta_{1}$ is positive.

We consider other variables associated with analysts' long-term forecasts. We control for the number of patents using a natural logarithm of patent counts at the end of the fiscal year. Demand for analyst research increases according to firm size [59]; larger firms tend to have greater investor concerns, and therefore greater demand, for analyst reports. We measure firm size (SIZE) as the natural logarithm of total assets. Analyst reports are associated with many factors, such as the debt ratio (LEV), operating performance $(R O A)$, and external financing activities (FIN) [60-62]. The debt ratio (LEV) is calculated by diving the total liabilities by total assets. Operating performance $(R O A)$ is measured by lagged return on assets. Following Bradshaw et al. [63], we measure firms' external financing activities (FIN) as the sum of net proceeds from equity financing and debt financing scaled by total assets. The proceeds from equity financing are measured by net cash received from the sale of common and preferred stock, less cash dividend paid. The proceeds from debt financing are measured by net cash received from the issuance of short- and long-term debt. To control for the complexity of analysts' research, we include COMP. Finally, we control for year and industry fixed effects in the regression model.

\subsection{Test of Patent Citations on the Direction of Long-Term Growth Forecasts by Analysts}

The second hypothesis states that the number of patent citations is associated with optimism in long-term forecasts by analysts. To test the hypothesis, we utilize the following equation:

$$
\begin{gathered}
\text { POS }_{t}=\alpha_{0}+\beta_{1} \text { CITE }_{t}+\beta_{2} \text { PATENT }_{t}+\beta_{3} \text { SIZE }_{t}+\beta_{4} L E V_{t} \\
+\beta_{5} R O A_{t}+\beta_{6} \text { FIN }_{t}+\beta_{7} \text { COMP }_{t}+\sum I N D+\sum Y R+\varepsilon_{t}
\end{gathered}
$$

where,

$\mathrm{POS}_{t}=$ Indicator variable set to 1 if the long-term forecast is higher than the short-term forecast, and 0 otherwise.

$P O S$ is an indicator variable that equals one if the long-term forecast is more positive than the short-term forecast, and zero otherwise. $\mathrm{H} 2$ predicts that $\beta_{1}$ is positive. The definitions of control variables in Equation (2) follow those in Equation (1).

\section{Results}

\subsection{Descriptive Statistics}

Table 2 presents the summary statistics for the variables used in this paper. The mean value of LONG is 0.928 , which represents $93 \%$ of analysts in our sample that issue long-term forecasts. The mean value and standard deviation of POS are 0.890 and 0.313 , respectively, which are comparable to 
statistics reported in prior studies [22]. The mean (median) value of CITE is 6.415 (6.629), which shows a similar pattern to those documented in [5,7]. Our observations have a mean (median) number of patents (PATENT) of 4.779 (4.934), with a standard deviation of 2.463.

Table 2. Descriptive Statistics.

\begin{tabular}{cccccc}
\hline Variables & Mean & STD & MIN & Median & MAX \\
\hline LONG $_{t}$ & 0.928 & 0.258 & 0.000 & 1.000 & 1.000 \\
POS $_{t}$ & 0.890 & 0.313 & 0.000 & 1.000 & 1.000 \\
CITE $_{t}$ & 6.415 & 2.918 & 0.000 & 6.629 & 11.905 \\
PATENT $_{t}$ & 4.779 & 2.463 & 0.693 & 4.934 & 9.415 \\
SIZE & 8.321 & 1.529 & 4.136 & 8.332 & 11.730 \\
LEV & 1.757 & 1.647 & 0.040 & 1.313 & 12.207 \\
ROA $_{t}$ & 0.061 & 0.066 & -0.219 & 0.059 & 0.244 \\
FIN $_{t}$ & -0.024 & 0.088 & -0.286 & -0.028 & 0.379 \\
COMP $_{t}$ & 9.462 & 17.971 & 1.000 & 6.000 & 144.000 \\
\hline
\end{tabular}

Table 3 reports the Pearson correlations. We find that the announcement of long-term forecasts is higher for firms with a greater number of patent citations (Panel A of Table 3). We also find that firms with more patent citations are more likely to receive more positive prospects (Panel B of Table 3). In addition, analysts are more likely to issue long-term forecasts for firms with greater assets, lower leverage, higher profitability, and greater financing activities. Furthermore, favorable long-term forecasts correlate with firms featuring smaller assets, lower leverage, higher profitability, and lower financing activities. Overall, our univariate results generally support the argument that patent information is associated with analysts' long-term forecasts.

Table 3. Correlation Matrix.

\begin{tabular}{|c|c|c|c|c|c|c|c|c|}
\hline \multicolumn{9}{|c|}{ Panel A. Variables for H1 } \\
\hline & $L O N G_{t}$ & CITE $_{t}$ & PATENT $_{t}$ & $S I Z E_{t}$ & $L E V_{t}$ & $R O A_{t}$ & $\boldsymbol{F I N}_{t}$ & $\mathrm{COMP}_{t}$ \\
\hline$L O N G_{t}$ & 1.000 & $\begin{array}{c}0.039 \\
(0.000)\end{array}$ & $\begin{array}{c}0.042 \\
(0.000)\end{array}$ & $\begin{array}{c}0.035 \\
(0.000)\end{array}$ & $\begin{array}{l}-0.026 \\
(0.000)\end{array}$ & $\begin{array}{c}0.049 \\
(0.000)\end{array}$ & $\begin{array}{c}0.008 \\
(0.035)\end{array}$ & $\begin{array}{l}-0.032 \\
(0.000)\end{array}$ \\
\hline $\mathrm{CITE}_{t}$ & & 1.000 & $\begin{array}{c}0.954 \\
(0.000)\end{array}$ & $\begin{array}{c}0.456 \\
(0.000)\end{array}$ & $\begin{array}{c}0.028 \\
(0.000)\end{array}$ & $\begin{array}{c}0.062 \\
(0.000)\end{array}$ & $\begin{array}{l}-0.119 \\
(0.000)\end{array}$ & $\begin{array}{l}-0.021 \\
(0.000)\end{array}$ \\
\hline PATENT $_{t}$ & & & 1.000 & $\begin{array}{c}0.458 \\
(0.000)\end{array}$ & $\begin{array}{c}0.028 \\
(0.000)\end{array}$ & $\begin{array}{c}0.063 \\
(0.000)\end{array}$ & $\begin{array}{l}-0.126 \\
(0.000)\end{array}$ & $\begin{array}{l}-0.006 \\
(0.093)\end{array}$ \\
\hline$S I Z E_{t}$ & & & & 1.000 & $\begin{array}{c}0.210 \\
(0.000)\end{array}$ & $\begin{array}{l}-0.022 \\
(0.000)\end{array}$ & $\begin{array}{l}-0.106 \\
(0.000)\end{array}$ & $\begin{array}{c}0.021 \\
(0.000)\end{array}$ \\
\hline$L E V_{t}$ & & & & & 1.000 & $\begin{array}{l}-0.260 \\
(0.000) \\
\end{array}$ & $\begin{array}{c}0.032 \\
(0.000) \\
\end{array}$ & $\begin{array}{c}0.028 \\
(0.000) \\
\end{array}$ \\
\hline$R O A_{t}$ & & & & & & 1.000 & $\begin{array}{l}-0.326 \\
(0.000)\end{array}$ & $\begin{array}{l}-0.015 \\
(0.000)\end{array}$ \\
\hline FIN $_{t}$ & & & & & & & 1.000 & $\begin{array}{l}-0.004 \\
(0.310)\end{array}$ \\
\hline $\mathrm{COMP}_{t}$ & & & & & & & & 1.000 \\
\hline \multicolumn{9}{|c|}{ Panel B. Variables for H2 } \\
\hline & $\mathrm{POS}_{t}$ & CITE $_{t}$ & PATENT $_{t}$ & $S I Z E_{t}$ & $L E V_{t}$ & $R O A_{t}$ & $F I N_{t}$ & $\mathrm{COMP}_{t}$ \\
\hline $\mathrm{POS}_{t}$ & 1.000 & $\begin{array}{c}0.011 \\
(0.002)\end{array}$ & $\begin{array}{c}0.007 \\
(0.051)\end{array}$ & $\begin{array}{l}-0.114 \\
(0.000)\end{array}$ & $\begin{array}{l}-0.014 \\
(0.000)\end{array}$ & $\begin{array}{c}0.007 \\
(0.064)\end{array}$ & $\begin{array}{l}-0.026 \\
(0.000)\end{array}$ & $\begin{array}{l}-0.004 \\
(0.237)\end{array}$ \\
\hline CITE $_{t}$ & & 1.000 & $\begin{array}{c}0.955 \\
(0.000) \\
\end{array}$ & $\begin{array}{c}0.468 \\
(0.000) \\
\end{array}$ & $\begin{array}{c}0.055 \\
(0.000) \\
\end{array}$ & $\begin{array}{c}0.055 \\
(0.000) \\
\end{array}$ & $\begin{array}{l}-0.116 \\
(0.000) \\
\end{array}$ & $\begin{array}{l}-0.018 \\
(0.000) \\
\end{array}$ \\
\hline PATENT $_{t}$ & & & 1.000 & $\begin{array}{c}0.469 \\
(0.000)\end{array}$ & $\begin{array}{c}0.054 \\
(0.000)\end{array}$ & $\begin{array}{c}0.056 \\
(0.000)\end{array}$ & $\begin{array}{l}-0.122 \\
(0.000)\end{array}$ & $\begin{array}{l}-0.002 \\
(0.617)\end{array}$ \\
\hline$S I Z E_{t}$ & & & & 1.000 & $\begin{array}{c}0.240 \\
(0.000) \\
\end{array}$ & $\begin{array}{l}-0.037 \\
(0.000) \\
\end{array}$ & $\begin{array}{l}-0.095 \\
(0.000)\end{array}$ & $\begin{array}{c}0.030 \\
(0.000)\end{array}$ \\
\hline$L E V_{t}$ & & & & & 1.000 & $\begin{array}{l}-0.266 \\
(0.000)\end{array}$ & $\begin{array}{c}0.045 \\
(0.000)\end{array}$ & $\begin{array}{c}0.029 \\
(0.000)\end{array}$ \\
\hline$R O A_{t}$ & & & & & & 1.000 & $\begin{array}{l}-0.335 \\
(0.000)\end{array}$ & $\begin{array}{l}-0.014 \\
(0.000)\end{array}$ \\
\hline FIN $_{t}$ & & & & & & & 1.000 & $\begin{array}{l}-0.004 \\
(0.239) \\
\end{array}$ \\
\hline$C O M P_{t}$ & & & & & & & & 1.000 \\
\hline
\end{tabular}




\subsection{Results}

Table 4 presents the coefficient estimates for testing hypothesis 1 from the ordinary least squares (OLS) regression with analysts' long-term forecasts $(L O N G)$ as the dependent variable. As predicted in hypothesis 1 , the coefficient of CITE is positive (0.065) and statistically significant at the $1 \%$ level ( $t$-statistics $=13.12)$, after controlling for the effects of number of acquired patents, firm size, leverage, firm profitability, and firms' financing activities. This significant positive result supports hypothesis 1 , indicating that analysts issue long-term forecasts for firms holding high quality patent stocks in response to investors' demand for firms with higher intangible assets. This may occur as a result of research regarding profitable firms generally generates more commission revenues [19].

Table 4. Patent citations and analysts' long-term forecasts.

\begin{tabular}{|c|c|c|}
\hline \multicolumn{3}{|c|}{$\begin{array}{c}L_{O N G}=\alpha_{0}+\beta_{1} \text { CITE }_{t}+\beta_{2} \text { PATENT }_{t}+\beta_{3} \text { SIZE }_{t}+\beta_{4} L E V_{t} \\
+\beta_{5} R O A_{t}+\beta_{6} \text { FIN }_{t}+\beta_{7} C O M P_{t}+\sum I N D+\sum Y R+\varepsilon_{t}\end{array}$} \\
\hline Variables & Coeff. & Wald Chi-Square \\
\hline Intercept & 1.153 & $31.39^{* * *}$ \\
\hline $\mathrm{CITE}_{t}$ & 0.065 & $13.12^{* * *}$ \\
\hline PATENT $_{t}$ & -0.056 & $6.18^{* *}$ \\
\hline$S I Z E_{t}$ & 0.137 & $113.09^{* * *}$ \\
\hline$L E V_{t}$ & -0.029 & $13.01^{* * *}$ \\
\hline$R O A_{t}$ & 3.137 & $206.57^{* * *}$ \\
\hline$F I N_{t}$ & 1.422 & $72.30^{* * *}$ \\
\hline $\mathrm{COMP} P_{t}$ & -0.006 & $91.95^{* * *}$ \\
\hline Industry Dummy & \multicolumn{2}{|c|}{ Included } \\
\hline Year Dummy & \multicolumn{2}{|c|}{ Included } \\
\hline Pseudo $R^{2}$ & \multicolumn{2}{|c|}{0.02} \\
\hline L. R. & \multicolumn{2}{|c|}{$1367.90^{* * *}$} \\
\hline $\mathrm{N}$ & \multicolumn{2}{|c|}{79,302} \\
\hline
\end{tabular}

Control variables employed in this study are the combined set of determinants of analyst reports examined in [59-62]. Consistent with [59], the coefficient of SIZE is significantly positive, supporting the argument that larger firms tend to receive more long-term forecasts. Not surprisingly, the coefficient of $L E V$ is significantly negative, meaning that firms with lower debt ratios have more long-term forecasts issued. The rest of the control variables are also consistent with expectations. Positive relationships are found between the issuance of long-term forecasts and firm profitability $(R O A)$, as well as financing activity $(F I N)[60,64]$.

Overall, the results for the number of patent citations support the hypothesis that analysts are more likely to issue long-term forecasts for firms with larger patent citations, since patent citations imply firms' growth opportunities, providing greater benefits for analysts who issue long-term forecasts.

Table 5 presents the results of hypothesis 2 . The coefficient of CITE is positive and significant at the $1 \%$ level. This is consistent with the prediction in hypothesis 2 that analysts using information on patent citations increase the frequency of long-term forecasts. Analysts recognize that patent citations lead to better future firm performance, and thus issue positive long-term forecasts, by considering the time required to realize visible outcomes from patenting activities. In other words, analysts view the number of patent citations as a signal of sustainable growth and, thereby, publish favorable long-term forecasts for patent-rich firms. 
Table 5. Patent citations and analysts' long-term forecasts.

\begin{tabular}{|c|c|c|}
\hline \multicolumn{3}{|c|}{$\begin{array}{l}\text { POS }_{t}=\alpha_{0}+\beta_{1} \text { CITE }_{t}+\beta_{2} \text { PATENT }_{t}+\beta_{3} \text { SIZE }_{t}+\beta_{4} L E V_{t} \\
\quad+\beta_{5} \text { ROA }_{t}+\beta_{6} \text { FIN }_{t}+\beta_{7} C O M P_{t}+\sum I N D+\sum Y R+\varepsilon_{t}\end{array}$} \\
\hline Variables & Coeff. & Wald Chi-square \\
\hline Intercept & 7.996 & $122.66^{* * *}$ \\
\hline $\mathrm{CITE}_{t}$ & 0.155 & $91.04^{* * *}$ \\
\hline PATENT $_{t}$ & -0.031 & 2.38 \\
\hline$S I Z E_{t}$ & -0.400 & $1190.59^{* * *}$ \\
\hline$L E V_{t}$ & 0.006 & 0.51 \\
\hline$R O A_{t}$ & -0.296 & 1.75 \\
\hline$F I N_{t}$ & -1.089 & $53.11^{* * *}$ \\
\hline$C O M P_{t}$ & 0.001 & 3.46 \\
\hline Industry Dummy & \multicolumn{2}{|c|}{ Included } \\
\hline Year Dummy & \multicolumn{2}{|c|}{ Included } \\
\hline Pseudo $R^{2}$ & \multicolumn{2}{|c|}{0.06} \\
\hline L. R. & \multicolumn{2}{|c|}{$4579.82^{* * *}$} \\
\hline $\mathrm{N}$ & \multicolumn{2}{|c|}{74,049} \\
\hline
\end{tabular}

Overall, the results in Tables 4 and 5 support hypotheses 1 and 2. Thus, patent citations promote the issuance of long-term forecasts because the number of patent citations plays a crucial role in sustainable growth. In addition, since patent citations entail future profits, the positive association between patent citations and positive analysts' forecasts is stronger in the long-term horizon, rather than in the short-term. In other words, long-term forecasts by analysts for firms with larger patent citations are likely to be more positive than short-term forecasts.

\subsection{Increases in Patent Citations and Analysts' Long-Term Growth Forecast Revisions}

In this section, we test whether the changes in patent citations affect the revision of growth forecasts. To test this relation, we used the 'increases in patent citations' variables, rather than 'accumulated patent citations' variables used in the previous analyses. The purpose of this analysis is to test the hypothesis that patent citation is a variable that explains a large portion of financial analysts' long-term forecasts. If financial analysts react to changes in patent citations, they are expected to modify existing growth forecasts. The regression analysis method using change variables reduces the effect of uncontrolled variables on a dependent variable, which can resolve the endogeneity problem to some degree [65]. As for the variable measurements, changes in patent citations are measured by deducting patent citations in the previous year from patent citations in the current year. Furthermore, the dependent variable is measured by subtracting firm's growth forecast for target year $t+1$ during year $\mathrm{t}$ from the firm's growth forecast for target year $t+1$ during year $t+1$. As long as the changes in patent citations affect analysts' prediction of long-term growth, the coefficient of changes in patent citations will show a significantly positive value.

Table 6 presents the regression results using the changes in patent citations as the independent variable. The results show that the coefficient of $\triangle C I T E$ is positive and significant at the $1 \%$ level. These results suggest that the higher the change in patent citations of firms, the more positively financial analysts tend to revise their long-term growth forecasts. 
Table 6. Increases in patent citations and analysts' long-term growth forecast revisions.

\begin{tabular}{|c|c|c|}
\hline \multicolumn{3}{|c|}{$\begin{array}{l}R E V_{t}=\alpha_{0}+\beta_{1} \Delta C I T E_{t}+\beta_{2} \Delta P A T E N T_{t}+\beta_{3} \Delta S I Z E_{t}+\beta_{4} \Delta L E V_{t} \\
\quad+\beta_{5} \Delta R O A_{t}+\beta_{6} \Delta F I N_{t}+\beta_{7} \Delta C O M P_{t}+\sum I N D+\sum Y R+\varepsilon_{t}\end{array}$} \\
\hline Variables & Coeff. & t-stat. \\
\hline Intercept & 0.093 & $1.89^{*}$ \\
\hline$\Delta$ CITE $_{t}$ & 0.048 & $3.45^{* * *}$ \\
\hline$\triangle$ PATENT $_{t}$ & -0.092 & $-4.70^{* * *}$ \\
\hline$\Delta S I Z E_{t}$ & -0.127 & $-5.71^{* * *}$ \\
\hline$\Delta L E V_{t}$ & -0.007 & $-1.66^{*}$ \\
\hline$\Delta R O A_{t}$ & 0.846 & $12.44^{* * *}$ \\
\hline$\Delta F I N_{t}$ & -0.234 & $-6.10^{* * * *}$ \\
\hline$\triangle C O M P_{t}$ & -0.000 & -1.20 \\
\hline Industry Dummy & \multicolumn{2}{|c|}{ Included } \\
\hline Year Dummy & \multicolumn{2}{|c|}{ Included } \\
\hline Adj. $R^{2}$ & \multicolumn{2}{|c|}{0.08} \\
\hline F-stat. & \multicolumn{2}{|c|}{$123.88^{* * *}$} \\
\hline $\mathrm{N}$ & \multicolumn{2}{|c|}{46,291} \\
\hline
\end{tabular}

$*, * *$, and ${ }^{* * *}$ indicate significance at the $10 \%, 5 \%$, and $1 \%$ levels, respectively. $R E V_{t}=$ (Growth forecast for firm i's target year $t+1$ during year $t+1)-($ Growth forecast for firm i's target year $t+1$ during year $t) ; \Delta C I T E_{t}=\left(C_{T} I T E_{t}\right.$ - CITE $\left._{t-1}\right) ; \Delta$ PATENT $_{t}=\left(\right.$ PATENT $_{t}-$ PATENT $\left._{t-1}\right) ; \Delta S I Z E_{t}=\left(\right.$ SIZE $_{t}-$ SIZE $\left._{t-1}\right) ; \Delta L E V_{t}=\left(L E V_{t}-L E V_{t-1}\right) ;$ $\Delta R O A_{t}=\left(R O A_{t}-R O A_{t-1}\right) ; \Delta F I N_{t}=\left(F^{\prime} N_{t}-F I N_{t-1}\right) ; \Delta C O M P_{t}=\left(C O M P_{t}-C O M P_{t-1}\right)$.

\subsection{High-Technology versus Low-Technology Firms}

High-technology firms emphasize invention and innovation in their business strategy by allocating a significant percentage of their financial resources to $R$ \& $D$. They typically employ a relatively high percentage of scientists and engineers, and competing in worldwide, short-life-cycle product markets [66]. Since high-technology firms develop advanced technology, they are often viewed as having potential for future growth. Hsu and Chang [67] observed a lower diversity in beliefs across financial analysts when firms in high technology industries submit intellectual capital information. In addition, financial analysts' forecasts are more accurate when firms disclose comprehensive information regarding intellectual capital. Therefore, the relationship between patent information and analysts' long-term forecasts depends on industry characteristics [68].

Table 7 presents results for the relationship between patent citations and long-term forecasts, according to technology intensity. We compare the coefficient of CITE for samples of high- vs. low-technology firms based on prior research [69] (We distinguish high-technology and low-technology firms according to the classification in Francis and Schipper [68]. The high-technology sample includes firms in chemical, allied products, industrial and commercial machinery, computer equipment, electronic, other electrical equipment, and components. The low-technology sample includes firms other than high-technology firms.). Consistent with our prediction, the magnitude of the CITE coefficient in high-technology firms ( 0.334 with $1 \%$ significance) is greater than in low-technology firms ( 0.255 with $1 \%$ significance), meaning that the relationship between patent citations and future firm performance is more pronounced for firms in high-technology industries. This result suggests that high-technology industries feature greater patent citations, resulting in the high frequency of long-term forecasts issued for patent-rich firms. 
Table 7. Patent citations and analysts' long-term forecasts by industry.

\begin{tabular}{|c|c|c|c|c|}
\hline $\operatorname{POS}_{t}=$ & \multicolumn{4}{|c|}{$\begin{array}{l}\alpha_{0}+\beta_{1} C I T E_{t}+\beta_{2} P A T E N T_{t}+\beta_{3} S_{I Z E_{t}}+\beta_{4} L E V_{t}+\beta_{5} R O A_{t}+\beta_{6} F I N_{t}+\beta_{7} \text { COMP }_{t} \\
+\sum I N D+\sum Y R+\varepsilon_{t}\end{array}$} \\
\hline \multirow{2}{*}{ Variables } & \multicolumn{2}{|c|}{ High-Technology Firms } & \multicolumn{2}{|c|}{ Low-Technology Firms } \\
\hline & Coeff. & Wald Chi-Square & Coeff. & Wald Chi-Square \\
\hline Intercept & 3.068 & $174.65^{* * *}$ & 4.729 & $903.97^{* * *}$ \\
\hline $\mathrm{CITE}_{t}$ & 0.334 & $66.32^{* * *}$ & 0.255 & $78.70^{* * *}$ \\
\hline PATENT $_{t}$ & -0.353 & $39.85^{* * *}$ & -0.161 & $19.89^{* * *}$ \\
\hline$S I Z E_{t}$ & -0.208 & $43.34^{* * *}$ & -0.509 & $834.72^{* * *}$ \\
\hline$L E V_{t}$ & -0.030 & $4.27^{* *}$ & 0.058 & $22.14^{* * *}$ \\
\hline$R O A_{t}$ & 1.878 & $27.28^{* * *}$ & -0.771 & $3.92^{* *}$ \\
\hline$F_{I}$ & -1.689 & $43.35^{* * *}$ & -1.387 & $32.16^{* * *}$ \\
\hline$C O M P_{t}$ & 0.002 & 1.88 & 0.002 & 2.49 \\
\hline Industry Dummy & \multicolumn{2}{|c|}{ Included } & \multicolumn{2}{|c|}{ Included } \\
\hline Year Dummy & \multicolumn{2}{|c|}{ Included } & \multicolumn{2}{|c|}{ Included } \\
\hline Pseudo $R^{2}$ & \multicolumn{2}{|c|}{0.04} & \multicolumn{2}{|c|}{0.08} \\
\hline L. R. & \multicolumn{2}{|c|}{$876.00^{* * *}$} & \multicolumn{2}{|c|}{$2,586.48^{* * *}$} \\
\hline $\mathrm{N}$ & \multicolumn{2}{|c|}{24,364} & \multicolumn{2}{|c|}{29,628} \\
\hline
\end{tabular}

\section{Conclusions}

Existing studies have shown that a firm's patents with high citations are positively related to its market value [5,31] and/or future financial performance [7,8]. Based on this empirical evidence, our study examines whether this positive effect of impactful patents on firm performance is considered by financial analysts in their forecasting activities. In particular, we focus on analysts' long-term forecasts, which are more dependent on intangible knowledge assets such as patents.

Our study finds that patent citation is positively associated with financial analysts' long-term forecasts, and this shows that patent information is considered by analysts in their forecasting behaviors. This suggests that patent citations can alleviate analysts' difficulty in resolving inherent uncertainty involved in predicting future outcomes of innovation activities. Our study also finds that industries with greater technology intensity show a stronger relationship between patent information and long-term forecasts issued. This suggests that forecasting based on patent citation would be particularly effective in evaluating technology-based firms.

Our findings have implications for understanding the impact of innovation on capital markets. Most technological innovations tend to require time before realizing positive financial outcomes. Therefore, it is difficult for technology-based firms to secure a stable supply of capital from capital markets, which is needed to sustain their innovation activities. Our findings show that financial analysts play an important role in resolving this dilemma, by providing investors with accurate evaluation of firms' innovation capability based on patent information. This behavior of financial analysts is very important in reducing the likelihood of capital market failure, by reducing the inherent uncertainty in technology investments, and ensuring stable supply of capital for firms to sustain innovation. Our findings also suggest that patent citation is considered a reliable indicator for the accurate evaluation of firms' knowledge assets such as patent stocks. Unlike other types of corporate assets, the future value of patent stocks is not easily determined, and thus, their effects on performance are hard to predict. In this situation, patent citations provide an effective alternative to financial analysts' direct evaluation of patents, because patent citation represents evaluation by other technology-based firms who have greater knowledge regarding technological fields.

In an innovation economy, knowledge assets have a growing importance in evaluating their future performance and market value. Although our study is focused on patent stocks, the impact of other intangible assets on sustainable growth has yet to be systematically evaluated. This would meet investors' demand for more information concerning those knowledge assets' effects on future firm 
value. The lack of investors' knowledge concerning the valuation impact of various intangible assets provides incentives for analysts to express how this information impacts firms' economic performance and sustainable growth. By extending our approach to other intangible assets including human resource and strategic partnerships, financial analysts are expected to play the role of providing relevant information to investors, by applying this information in future earnings forecasts and stock recommendations. This helps investors make better investment decisions.

Acknowledgments: This work was supported by SMBA (Small and Medium Business Administration) and Inha Entrepreneurship Center.

Author Contributions: Jaimin Goh and Wonchang Hur conceived and developed the hypotheses and the experiments, Jincheol Bae prepared the data and performed the analysis, and Jaehong Lee and Jincheol Bae wrote the paper.

Conflicts of Interest: The authors declare no conflict of interest.

\section{References}

1. Arvidsson, S. The corporate communication process between listed companies and financial analysts. Corp. Commun. Int. J. 2012, 17, 98-112. [CrossRef]

2. Griliches, Z. Patent statistics as economic indicators: A survey. J. Econ. Lit. 1990, 28, 1661-1707.

3. Trajtenberg, M. The welfare analysis of product innovations with an application to computed tomography scanners. J. Political Econ. 1990, 97, 445-479. [CrossRef]

4. Harhoff, D.; Narin, F.; Scherer, F.M.; Vopel, K. Citation frequency and the value of patented inventions. Rev. Econ. Stat. 1999, 81, 511-515. [CrossRef]

5. Hall, B.H.; Jaffe, A.; Trajtenberg, M. Market value and patent citations. RAND J. Econ. 2005, 36, 16-38.

6. Nakata, Y.; Ward, M.R.; Zhang, X. The market value of patenting: New findings from Japanese firm level data. Unpublished paper. 2011.

7. Gu, F. Innovation, future earnings, and market efficiency. J. Account. Audit. Financ. 2005, 20, 385-418.

8. Pandit, S.; Wasley, C.E.; Zach, T. The effect of research and development (R \& D) inputs and outputs on the relation between the uncertainty of future operating performance and R \& D expenditures. J. Account. Audit. Financ. 2011, 26, 121-144.

9. Stickel, S.E. Common stock returns surrounding earnings forecast revisions: More puzzling evidence. Account. Rev. 1991, 66, 402-416.

10. Gleason, C.; Lee, C. Analyst forecast revisions and market price discovery. Account. Rev. 2003, 78, $193-225$. [CrossRef]

11. Womack, K.L. Do brokerage analysts' recommendations have investment value? J. Financ. 1996, 51, $137-168$. [CrossRef]

12. Jegadeesh, N.; Kim, J.; Krische, S.; Lee, C. Analyzing the analysts: When do recommendations add value? J. Financ. 2004, 59, 1083-1124. [CrossRef]

13. Brown, P.; Foster, G.; Noreen, E. Security Analyst Multi-Year Earnings Forecasts and the Capital Markets; American Accounting Association: Sarasota, FL, USA, 1985.

14. Bandyopadhyay, S.P.; Brown, L.D.; Richardson, G.D. Analysts' use of earnings forecasts in predicting stock returns: Forecast horizon effects. Int. J. Forecast. 1995, 11, 429-445. [CrossRef]

15. Bradshaw, M.T. How do analysts use their earnings forecasts in generating stock recommendations? Account. Rev. 2004, 79, 25-50. [CrossRef]

16. Barth, M.; Clinch, G. Revalued financial, tangible, and intangible assets: Associations with share prices and non-market based value estimates. J. Account. Res. 1998, 36, 199-233. [CrossRef]

17. Cohen, J.R.; Holder-Webb, L.L.; Nath, L.; Wood, D. Corporate reporting of nonfinancial leading indicators of economic performance and sustainability. Account. Horiz. 2012, 26, 65-90. [CrossRef]

18. Fernández, B.; Callen, Y.; Gadea, J. Stock price reaction to non-financial news in European technology companies. Eur. Account. Rev. 2011, 20, 81-111. [CrossRef]

19. McNichols, M.; O'Brien, P.C. Self-selection and analyst coverage. J. Account. Res. 1997, 35, 167-199. [CrossRef]

20. Hullmann, A.; Meyer, M. Publications and patents in nanotechnology. Scientometrics 2003, 58, 507-527. [CrossRef] 
21. Botosan, C.; Plumlee, M. Assessing alternative proxies for the expected risk premium. Account. Rev. 2005, 80, 21-54. [CrossRef]

22. Jung, B.; Shane, P.B.; Yang, Y.S. Do financial analysts' long-term growth forecasts matter? Evidence from stock recommendations and career outcomes. J. Account. Econ. 2012, 53, 55-76. [CrossRef]

23. Lev, B. Intangibles: Management, Measurement, and Reporting; Brookings Institution Press: Washington, DC, USA, 2001.

24. O'Donnell, F.; O’Regan, P.; Coates, B.; Kenedy, T.; Keary, B.; Bekery, G. Human interaction: The critical sources of intangible value. J. Intellect. Cap. 2003, 4, 82-99. [CrossRef]

25. Demediuk, P. Intellectual capital reporting: New accounting for the new economy. Asian Acad. Manag. J. 2002, 7, 57-74.

26. Lee, B.; Cho, H.H.; Shin, J. The relationship between inbound open innovation patents and financial performance: Evidence from global information technology companies. Asian J. Technol. Innov. 2015, 23, 289-303. [CrossRef]

27. Lieberman, M.B.; Montgomery, D.B. First-mover advantages. Strateg. Manag. J. 1988, 9, 41-58. [CrossRef]

28. Hall, B.; Jaffe, A.; Trajtenberg, M. Market value and patent citations: A first look. Unpublished paper. 2000.

29. Zhang, X. Market Value of Patent Citations: New Findings from Japanese Firms; Department of Economics, Okayama University: Okayama, Japan, 2008; pp. 1-61.

30. Narin, F.; Noma, E.; Perry, R. Patents as indicators of corporate technological strength. Res. Policy 1987, 16, 143-155. [CrossRef]

31. Hirschey, M.; Richardson, V.J.; Scholz, S. Value relevance of nonfinancial information: The case of patent data. Rev. Quant. Financ. Account. 2001, 17, 223-235. [CrossRef]

32. Bresnahan, T.F. Post-entry competition in the plain paper copier market. Am. Econ. Rev. 1985, 75, 15-19.

33. Gu, F.; Lev, B. The information content of royalty income. Account. Horiz. 2004, 18, 1-12. [CrossRef]

34. Cohen, L.; Diether, K.; Malloy, C. Misvaluing innovation. Rev. Financ. Stud. 2013, 26, 635-666. [CrossRef]

35. Rong, Z. Do insider trading patterns indicate a firm's R\&D productivity: Evidence from U.S. patenting firms. J. Account. Financ. 2012, 12, 118-132.

36. Gu, F.; Wang, W. Intangible assets, information complexity, and analysts' earnings forecasts. J. Bus. Financ. Account. 2005, 32, 1673-1702. [CrossRef]

37. Amir, E.; Lev, B.; Sougiannis, T. Do financial analysts get intangible? Eur. Account. Rev. 2003, 12, $635-659$. [CrossRef]

38. Livnat, J.; Zhang, Y. Information interpretation or information discovery: Which role of analysts do investors value more? Rev. Account. Stud. 2012, 17, 612-641. [CrossRef]

39. Barker, R. The market for information-evidence from finance directors, analysts and fund managers. Account. Bus. Res. 1998, 29, 3-20. [CrossRef]

40. Holland, J.; Johansom, U. Value-relevant information on corporate intangibles-creation, use, and barriers in capital markets-“between a rock and a hard place”. J. Intellect. Cap. 2003, 4, 465-486. [CrossRef]

41. Bradshaw, M.T.; Drake, M.T.; Myers, J.N.; Myers, L.A. A re-examination of analysts' superiority over time-series forecasts of annual earnings. Rev. Account. Stud. 2012, 17, 944-968. [CrossRef]

42. Brown, L.D.; Hagerman, R.L.; Griffin, P.A.; Zmijewski, M.E. An evaluation of alternative proxies for the market's assessment of unexpected earnings. J. Account. Econ. 1987, 9, 159-193. [CrossRef]

43. Kothari, S.P. Capital markets research in accounting. J. Account. Econ. 2001, 31, 105-231. [CrossRef]

44. Gordon, M.J. The Investment, Financing, and Valuation of the Corporation; R.D. Irwin: Homewood, IL, USA, 1962.

45. Copeland, T.; Dolgoff, A.; Moel, A. The role of expectations in explaining the cross-section of stock returns. Rev. Account. Stud. 2004, 9, 149-188. [CrossRef]

46. DeFond, M.L.; Hung, M. An empirical analysis of analysts' cash flow forecasts. J. Account. Econ. 2003, 35, 73-100. [CrossRef]

47. Ljungqvist, A.; Marston, F.C.; Starks, L.T.; Wei, K.D.; Hong, Y. Conflicts of interest in sell-side research and the moderating role of institutional investors. J. Financ. Econ. 2007, 85, 267-296. [CrossRef]

48. Rozeff, M.S. Predicting long-term earnings growth: Comparisons of expected return models, submartingales and value line analysts. J. Forecast. 1983, 2, 425-435. [CrossRef]

49. La Porta, R. Expectations and the cross-section of stock returns. J. Financ. 1996, 51, 1715-1742. [CrossRef]

50. Dechow, P.M.; Sloan, R.G. Returns to contrarian investment strategies: Tests of naive expectations hypotheses. J. Financ. Econ. 1997, 43, 3-27. [CrossRef] 
51. Hong, H.; Kubik, J.D.; Solomon, A. Security analysts' career concerns and herding of earnings forecasts. RAND J. Econ. 2000, 31, 121-144. [CrossRef]

52. Chen, X.; Cheng, Q.; Lo, K. On the relationship between analyst reports and corporate disclosures: Exploring the roles of information discovery and interpretation. J. Account. Econ. 2010, 49, 206-226. [CrossRef]

53. Maines, L.A.; McDaniel, L.S. Effects of comprehensive-income characteristics on nonprofessional investors' judgments: The role of financial-statement presentation format. Account. Rev. 2000, 75, 179-207. [CrossRef]

54. Financial Accounting Standards Board. Improving Business Reporting: Insights into Enhancing Voluntary Disclosures; Financial Accounting Standards Board: Norwalk, CT, USA, 2001.

55. Securities and Exchange Commission. Strengthening Financial Markets: Do Investors Have the Information They Need? Securities and Exchange Commission: Washington, DC, USA, 2001.

56. Schumpeter, J.A. The Theory of Economic Development: An Inquiry into Profits, Capital, Credit, Interest, and the Business Cycle; Transaction Publishers: Piscataway, NJ, USA, 1934.

57. Lanjouw, J.; Schankerman, M. Characteristics of patent litigation: A window on competition. RAND J. Econ. 2001, 32, 129-151. [CrossRef]

58. Simon, A.; Nowlan, J. Long-term growth forecasts and stock recommendation profitability. Asia-Pa. J. Account. Econ. 2015, 22, 163-190. [CrossRef]

59. Lang, M.; Lundholm, R. Corporate disclosure policy and analyst behavior. Account. Rev. 1996, 71, 467-492.

60. Bhushan, R. Firm characteristics and analyst following. J. Account. Econ. 1989, 11, 255-274. [CrossRef]

61. Dechow, P.; Dichev, I. The quality of accruals and earnings: The role of accrual estimation errors. Account. Rev. 2002, 77, 35-59. [CrossRef]

62. Kasznik, R. On the association between voluntary disclosure and earnings management. J. Account. Res. 1999, 37, 57-81. [CrossRef]

63. Bradshaw, M.; Richardson, S.; Sloan, R. The relation between corporate financing activities, analysts' forecasts and stock returns. J. Account. Econ. 2006, 42, 53-85. [CrossRef]

64. Yu, F. Analyst coverage and earnings management. J. Financ. Econ. 2008, 88, 245-271. [CrossRef]

65. Liker, J.K.; Augustyniak, S.; Duncan, G.J. Panel data and models of change: A comparison of first difference and conventional two-wave models. Soc. Sci. Res. 1985, 14, 80-101. [CrossRef]

66. Milkovich, G.T. Compensation Systems in High Technology Companies; Prentice-Hall: Englewood Cliffs, NJ, USA, 1987.

67. Hsu, W.; Chang, Y. Intellectual capital and analyst forecast: Evidence from the high-tech industry in Taiwan. Appl. Financ. Econ. 2011, 21, 1135-1143. [CrossRef]

68. Skinner, D. Accounting for intangibles-A critical review of policy recommendations. Account. Bus. Res. 2008, 38, 191-204. [CrossRef]

69. Francis, J.; Schipper, K. Have financial statements lost their relevance. J. Account. Res. 1999, 37, 319-352. [CrossRef]

(C) 2017 by the authors. Licensee MDPI, Basel, Switzerland. This article is an open access article distributed under the terms and conditions of the Creative Commons Attribution (CC BY) license (http://creativecommons.org/licenses/by/4.0/). 